\title{
Zoysiagrass (Zoysia spp. Willd.) for European lawns: A review
}

\author{
Simone Magni, ${ }^{1}$ Antonio Pompeiano, ${ }^{2}$ Monica Gaetani, ${ }^{1}$ Lisa Caturegli, ${ }^{3}$ Nicola Grossi, ${ }^{1}$ \\ Alberto Minelli, ${ }^{3}$ Marco Volterrani ${ }^{1}$ \\ ${ }^{1}$ Department of Agriculture, Food and Environment, University of Pisa, Pisa, Italy; ${ }^{2}$ Laboratory of Plant \\ Ecological Physiology, Global Change Research Centre, Czech Academy of Sciences, Brno, Czech Republic; \\ ${ }^{3}$ Department of Agricultural Sciences, University of Bologna, Bologna, Italy
}

\begin{abstract}
In Europe the cultivation of warm season turfgrasses was negligible until the beginning of the 90's. A scientific approach to their cultivation started with field trials being installed in several locations in Italy starting from 1994. Adaptation to climatic condition and first screening of relative performance of cultivars were held as primary elements to assess in order to assist turf growers in introducing the different species and cultivars of zoysiagrass (Zoysia spp. Willd.) in the warm temperate regions of Mediterranean Europe. At a later stage, studies on zoysiagrass adaptation were extended as north as $45^{\circ}$ parallel and, as slow establishment began to appear a major limitation of this turfgrass, an alternative establishment method and establishment pattern were investigated. As for other warm season turfgrasses winter dormancy is considered a major drawback and trials dealing with fall fertilisation and winter management have been carried out to support winter maintenance decisions. In recent years soccer playing characteristics have been determined on zoysiagrass, while preliminary research results indicate turf management through remotely sensed data as a promising technique for the years to come.
\end{abstract}

Correspondence: Marco Volterrani, Department of Agriculture, Food and Environment, University of Pisa, via del Borghetto 80, 56124 Pisa, Italy.

E-mail: marco.volterrani@unipi.it

Key words: Adaptation; Establishment; Stress tolerance; Remote sensing; Sports use.

Disclaimer: chemical products, their relative application rates and intended uses are reported in this paper solely as review of existing scientific literature and may not conform to product label. Use of chemical products according to label directions is recommended. Beyond label directions, European Union and Member States regulations define specific restrictions to the use of chemicals for ornamental plants.

Received for publication: 24 January 2017.

Revision received: 4 May 2017.

Accepted for publication: 6 May 2017.

CCopyright S. Magni et al., 2017

Licensee PAGEPress, Italy

Italian Journal of Agronomy 2017; 12:925

doi:10.4081/ija.2017.925

This article is distributed under the terms of the Creative Commons Attribution Noncommercial License (by-nc 4.0) which permits any noncommercial use, distribution, and reproduction in any medium, provided the original author(s) and source are credited.

\section{Introduction}

The use of warm season turfgrasses to establish lawns and turfs in Europe is limited to the warm humid and warm arid areas of the continent. Most of the coastal regions of the Mediterranean basin are elective environments for warm season grasses; nonetheless, only southern borders of this broader area provide climatic conditions that support year-round green cover. Most of the European territory falls in fact, under the turfgrass transition zone, where warm season turfgrasses can be grown successfully but dormancy occurs to some extent during the cooler months (Volterrani et al., 1997).

The genus Zoysia Willdenow (or Willd.) is indigenous of the western Pacific Rim and Indian Ocean and it has been recognised to consist of 11 species that include:

\section{Z. japonica Steudel}

Z. macrantha Desvaux

Z. macrostachya Franchet \& Savatier

Z. matrella (L.) Merrill

Z. minima (Colenso) Zotov

Z. pacifica (Goudswaard) Hotta \& Kuroki

Z. pauciflora $\mathrm{Mez}$

Z. planifolia Zotov

Z. seslerioides (Balansa) Claton \& Richardson

Z. sinica Hance

Z. tenuifolia Thiele.

The use as turfgrass is limited to Z. japonica, Z. matrella and $Z$. pacifica and to some man-made hybrids $Z$. japonica $\times$ matrella and $Z$. japonica $\times$ pacifica, however many of the commercial cultivars are intermediate forms as hybrids across species. One commercial cultivar of the species $Z$. macrantha has been registered (Layt, 2011) and is being sold in Australia.

Depending on the tendency of phenotypic traits, the nomenclature of japonica type and matrella type or fine-leaf zoysiagrasses can be found in literature (Engelke et al., 2003; Foy, 2006).

To authors' knowledge, a first mention of cultivation of warm season turfgrasses in general, and of zoysiagrass in particular, can be found in an Italian turf textbooks dating back to 1972 in which information is mainly derived from the United States of America (Panella, 1972).

Despite a vast knowledge available from the United States and that first attempt to bring it in the European context, at that time the leading idea of turf was inspired by the manicured lawns and sport surfaces grown in Northern Europe with Great Britain being considered the reference for quality standards and for every aspect of turfgrass cultivation. An English-fashion lawn was, and sometimes is still today, considered the ideal turf. Still in 1993 a survey compiled on breeding advances of turfgrasses in Europe was based on the official result of tests carried out in France, Germany and the Netherlands (van Wijk, 1993). Other turfgrass evaluation programs mentioned in the survey were conducted in Scandinavia 
and the United Kingdom this describing an European turfgrass sector mainly developed in central-northern regions and limited to the cool season turfgrass species. The prevailing turfgrass culture that had developed on cool season species may have contributed to the late introduction of warm season turfgrasses in Europe with their cultivation being in fact negligible until the beginning of the 90's. The history of zoysiagrass largely overlaps with that of other major warm season turfgrasses and a scientific approach to cultivation started with field trials being installed in several locations in Italy since 1994 (Volterrani et al., 1996).

The objective of this paper is to provide a comprehensive collection of published literature through which to describe the advances made in use and culture of zoysiagrass in Europe since the first research activities that were set up in the continent. An indirect evaluation of the actual relevance of zoysiagrass for the European turfgrass industry is also provided based on the experience of academics and practitioners who shared their personal knowledge.

\section{Adaptation to the European environment}

First experimental activities dealing with zoysiagrass adaptation were intended to assess the adaptability of warm season turfgrasses in general with bermudagrass [Cynodon spp. (L.) Rich.] and seashore paspalum (Paspalum vaginatum Swartz) being often associated to zoysiagrass in field trials. In a field study of Volterrani et al. (1996) three cultivars of Z. japonica (El Toro, Meyer and Asiak), Z. pacifica and Z. japonica $\times$ pacifica Emerald were tested in irrigated and non irrigated plots. While other warm season turfgrasses, namely Santa Ana bermudagrass, seashore paspalum and the cool season Festuca arundinacea Schreb (tall fescue) were able to provide an acceptable turf quality throughout the trial period, both in irrigated and non irrigated conditions, zoysiagrasses failed to maintain a sufficient quality without irrigation. Over a five-year period Z. japonica El Toro yielded the best quality among zoysiagrasses. Also recuperative capacity appeared to be strongly dependent on irrigation. Zoysiagrasses were found to be the species with the most prolonged winter vegetative activity. $Z$. pacifica and Z. japonica $\times$ pacifica had the shortest winter dormancy period (from 1 to 2.5 months over a 5 years period) while in $Z$. japonica the brown period lasted for a period ranging from 2.5 to 4 months (Miele et al., 2000).

Due to the lack of readily available vegetative propagation material, at the early stages of zoysiagrass introduction seeded varieties raised particular interest. In a field trial carried out from 1995 through 2000 in Rome five vegetative zoysiagrass cultivars were compared with four seeded cultivars. These first results indicated that, despite no differences were observed between vegetatively and seed propagated cultivars as to green canopy biomass and root biomass, the five vegetative cultivars of zoysiagrass ranked higher in turfgrass quality compared to the seeded ones. This difference was partially attributed to a differential susceptibility to rust (Puccinia spp.) in the trial environment. Mowing quality was judged poor for all the entries except for De Anza. The cultivars El Toro, W3-2 and J-36 were scored as the slowest to green up in spring while Victoria, De Anza and Emerald were those giving the best performance as to fall colour retention (Croce et al., 1999, 2001, 2004).

Following the good adaptation of zoysiagrass at Rome and Pisa latitudes $\left(41^{\circ} 40^{\prime} \mathrm{N}\right.$ and $43^{\circ} 40^{\prime} \mathrm{N}$ respectively) a new trial testing establishment and adaptation was installed at Padua latitude $\left(45^{\circ} 42^{\prime}\right.$ N). Z. japonica El Toro, and Z. matrella (L.) Merr. (manilagrass) Zeon were established by sprigging while $Z$. japonica Zenith was seeded. After a three-year observation period, the establishment rate of the zoysiagrasses was the slowest compared to other warm season turfgrasses and the complete ground cover was reached after two growing seasons. Some winter injury did occur in 2006 causing a slight delay in spring green up of vegetative zoysiagrass cultivars. On the other hand all zoysiagrasses had superior fall colour retention and, throughout the trial period, manilagrass received the best quality score over all entries (De Luca et al., 2008).

Differently from data and general impressions gathered in Italy, in a trial carried out in Izmir (Turkey) Meyer and Zenith zoysiagrasses performed as the slowest entries to establish among other warm season turfgrasses. Despite soil $\mathrm{pH}$ was indicated as a likely cause of slow growth rate, the slow establishment rate coupled with a long winter dormancy made authors conclude that zoysiagrass was not a promising turfgrass choice under the experimental conditions (Geren et al., 2009).

Winter dormancy is ever since considered the main drawback to a wide acceptance of warm season turfgrasses in the transition zone due to a loss of color and a growth arrest during winter months. In 2009 and 2010 at Pisa University Pompeiano et al. (2014b) carried out a field trial specifically directed to zoysiagrass winter color retention and spring green up. The trial included 5 entries of Z. japonica (De Anza, El Toro, Victoria, Meyer and Zenith), and 5 entries belonging to the fine-leaved zoysiagrasses with two cultivars of Z. matrella (Zeon and DALZ 0101), two interspecific hybrids of $Z$. japonica $\times$ pacifica (Emerald and HT 210 ) and one entry of $Z$. pacifica. In the study some general trends were described and found accordance with previous knowledge. In particular fine-leaved zoysiagrasses were found to have a significantly better winter colour retention compared to Japanese lawngrasses that had a faster entrance in the dormancy period. On the other hand Japanese lawngrasses had on average an earlier spring green up compared to the fine-leaved ones. The overall effect on winter dormancy period was highly cultivar specific. As to $Z$. japonica genotypes early green up was observed in Zenith and Meyer while fall colour retention was better in De Anza, El Toro and Victoria. The cultivar El Toro resulted the Japanese lawngrass with the shortest dormant period. As to the fine-leaved entries less variability was found. Emerald and Zeon had an early green up but not consistently though the years, while fall colour retention was consistently lower in HT210 compared to other fine-leaved zoysiagrasses.

The introduction of warm season turfgrasses in the coastal area of Turkey was studied also by Severmutlu et al. (2011a) in a twoyear trial carried out in two locations. Two seed propagated zoysiagrasses (Zenith and Companion) were included in the trial. Relative to establishment, 18 weeks after seeding both cultivars reached on average $87 \%$ ground cover in the Antalya location and 98\% ground cover in the Mersin location. At both locations full dormancy lasted 6 to 8 weeks while acceptable green quality was observed for 7.5 months. Zenith had superior quality and colour compared to Companion. Zoysiagrasses exhibited early spring green up compared to other warm season turfgrasses included in the trial.

\section{Establishment}

While gaining acceptance among turf managers, some failures 
were experienced in Italy during the establishment of vegetatively propagated zoysiagrasses due to insufficient viability of sprigs, uneven distribution, poor sprig to soil contact and sprig desiccation due to non uniform water distribution. When plugging was adopted to overcome sprigging problems an uneven surface was attained. With the aim of providing turf managers a reliable source of vegetative material and a standardised method of planting, a new establishment method was developed and tested in Italy. This method is based on growing sprigs in greenhouse conditions inside cell trays until they develop roots and shoots. Following, plants are mechanically transplanted in soil at a given spacing and growing-in encouraged through irrigation, fertilisation and mowing as for standard establishment methods. The method proved particularly beneficial in a trial including zoysiagrasses. Z. japonica Zenith and Z. matrella Zeon planted at the density of 11.1 plants per square meter completed their establishment within one growing season at 16 and 18 weeks after transplanting respectively (Volterrani et al., 2008).

In a trial carried out in 2006 establishment rate of isolated plants grown in large containers was determined on 5 cultivars of Z. japonica (De Anza, El Toro, Victoria, Meyer and Zenith), two cultivars of Z. matrella (Zeon and DALZ 0101), two interspecific hybrids of Z. japonica $\times$ pacifica (Emerald and HT 210) and one entry of $Z$. pacifica. A genotype effect was recorded but it could not be attribute solely to the species. In general ground cover expansion was associated with stolon growth rate, however the number of stolons and stolon and rhizome branching yielded different colonising capabilities of the entries. As a group, Japanese lawngrass produced longer and thicker horizontal stems while manilagrass balanced with a superior density (Pompeiano et al., 2012).

Slow establishment is as a limiting factor when considering zoysiagrass use and even more was perceived a drawback during the introduction of zoysiagrass as new turfgrass species. With the aim of determining the establishment rate on a broader sample of plant material, establishment rate and stolon growth were studied in a field trial on ten entries belonging to different grouping of zoysiagrasses. In particular a study started in Pisa in 2007 included 5 cultivars of $Z$. japonica (De Anza, El Toro, Victoria, Meyer and Zenith), two cultivars of $Z$. matrella (Zeon and DALZ 0101), two interspecific hybrids of Z. japonica $\times$ pacifica (Emerald and HT 210) and one entry of $Z$. pacifica. The fastest to establish were El Toro and De Anza even if, probably due to a low planting density of 2.9 spaced plants per square meter, establishment was completed the year following transplant. The hybrid HT 2010 and Z. pacifica were the slowest to reach full ground cover. On the other hand Z. pacifica and hybrid entries gave the best quality. The entries with the higher linear stolon growth resulted the fastest in establishment (Volterrani et al., 2010a).

\section{Drought tolerance}

Drought resistance in Mediterranean conditions was studied by Severmutlu et al. (2011b). In a field comparison Zenith and Compadre zoysiagrasses and other warm season turfgrasses were subject to a 90 days drought stress. The poorest green color retention and the complete leaf firing reported on zoysiagrasses indicated an inferior drought resistance compared with the other warm season turfgrasses included in the trial. Sixty days after drought stress zoysiagrass had the slowest recovery among the entries, this well describing the moderate drought tolerance of zoysiagrasses.

Rimi et al. (2012b) studied the association existing between turf quality and root system architecture in four warm season turfgrasses grown under non-irrigated conditions in the Mediterranean transition zone. When comparing turf quality of Companion zoysiagrass with three different bermudagrasses, best quality scores were attributed to zoysiagrass in April, May and November while from June to September bermudagrass yielded the best quality, this suggesting poor adaptation of zoysiagrass to non-irrigated conditions. Data describing root system architecture confirmed that turf quality was positively correlated to root density in mass and length in the $25-40 \mathrm{~cm}$ soil layer with deep rooting turfgrasses having an advantage in periods of soil moisture deficit. Similar observations were made for turfgrass colour (Macolino et al., 2012).

\section{Heat stress tolerance}

A controlled environment experiment where $C$. dactylon $\times$ transvaalensis Burtt-Davy Tifway and Z. japonica Meyer were subject to heat stress $\left(47+/-1^{\circ} \mathrm{C}\right.$ for increasing time ranging from 6 to $168 \mathrm{~h}$ ) revealed that zoysiagrass has a moderate tolerance to heat stress compared to bermudagrass. After a $6 \mathrm{~h}$ period of stress zoysiagrass canopy recovery exhibited a sharp decline whereas bermudagrass maintained an unaltered plant regrowth response until $96 \mathrm{~h}$ of exposure. In the study the greater susceptibility of zoysiagrass to heat stress was associated with a lower ability to modulate its response to stress as to chlorophyll breakdown, total soluble sugars content and protein expression (Pompeiano et al., 2013b).

\section{Salinity tolerance and alleviation}

The ability of stolons of $C$. dactylon $\times$ transvaalensis Tifway, $P$. vaginatum Salam and $Z$. matrella Zeon to produce roots and shoots in increasingly saline conditions was investigated by Gaetani et al. (2013). When exposed to salinity levels of 1 (control), 16, 39, 53 and $70 \mathrm{dS} \mathrm{m}^{-1} Z$. matrella stolons gave the worst performance with shoot and root growth being suppressed at salinity level of $16 \mathrm{dS}$ $\mathrm{m}^{-1}$ and shoot sprouting being virtually inhibited at higher salinity values. Authors concluded that little possibility exists for vegetative establishment of $Z$. matrella Zeon in saline conditions, however wide variability has been documented in salt tolerance of different groups of zoysias (Qian et al., 2014) and cultivar specific response to salt stress is probably to be expected also during vegetative establishment.

The effect of nitrogen application to alleviate salinity stress was studied in a controlled environment trial. Z. matrella Zeon cores taken from a mature stand were expose for 6 weeks to salinity level of 0,15 and $30 \mathrm{dS} \mathrm{m}^{-1}$ via hydroculture. The low tolerance of zoysiagrass to salinity stress was highlighted by a sharp decrease in clippings and verdure dry weight, shoot density and the application of nitrogen in soluble form (from ammonium sulphate) equivalent to 50 and $100 \mathrm{~kg} \mathrm{ha}^{-1}$ of nitrogen had negligible effect to alleviate adverse effects of the salinity stress (Pompeiano et al., 2014a). 


\section{Winter colour loss and management}

In a field trial carried out in years 2011-2012, Pompeiano et al. (2015) investigated the patterns of color loss during winter and the associated physiological modifications in zoysiagrasses. With this aim entries belonging to the japonica type (El Toro and Meyer) and fine leaved type (Zeon and Z. pacifica) were selected for their contrasting performances as to winter colour retention and spring green up. As expected Japanese lawn grasses exhibited poor colour retention, faster green up and longer dormancy period compared to the fine-leaved zoysiagrass genotypes. In Japanese lawn grasses the decline of photosynthetic pigments (chlorophyll a chlorophyll $\mathrm{b}$ and carotenoids) was similar to that observed in colour retention while fine-leaved zoysiagrasses had a less severe degradation of pigments. Similarly, starch concentration in horizontal stems declined as Japanese lawngrass senescence progressed while Zeon had few changes in starch levels and Z. pacifica showed an accumulation of this reserve carbohydrate. As to total soluble sugars three out of zoysiagrasses shared a similar pattern of accumulation and depletion associate respectively with senescence and green up.

Compared to other warm season turfgrasses, zoysiagrasses are known to exhibit the best color retention in winter with Z. matrella retaining colour longer than $Z$. japonica. In order to further extend colour retention in winter, late fall application of nitrogen was studied with specific reference to application timing in the fall. Results showed that application of $20 \mathrm{~g} \mathrm{~m}^{-2}$ of nitrogen carried out at different dates in October yielded an acceptable colour until the third week of December. The positive effect extended to January for the application made the last week of October. However delaying nitrogen application to the first week of November resulted in a poor winter color enhancement with a negative effect on spring green up (Volterrani et al., 2010b).

The effect of late nitrogen application on Z. matrella has been investigated also in a controlled environment study. Plants left to acclimate under natural environmental conditions were fertilised with 15 and $30 \mathrm{~g} \mathrm{~m}^{-2}$ of nitrogen on 20 September, assumed as falling in the period of fall growth decline. Plants were then collected at monthly intervals, exposed to freezing conditions and their freeze tolerance determined as $\mathrm{LT}_{50}$ (temperature causing lethal damage to half of the sample). While confirming the effect of a prolonged green period of the fertilised plants over the control, the higher fertilisation rate induced a sharp decrease of freeze tolerance in October. Beneficial effects of fertilisation in terms of freeze tolerance were instead observed in February and January, with only the $30 \mathrm{~g} \mathrm{~m}^{-2}$ rate producing such effect till March (Pompeiano et al., 2011).

The effect of late season nitrogen fertilisation was studied also with respect to nitrogen source. In controlled environment trial, two nitrogen sources (ammonium sulphate and calcium nitrate) were applied to Tifway bermudagrass and Zeon zoysiagrass plants and their freeze tolerance determined. Results indicated that two weeks after fertiliser application the ammonium source produced a detrimental effect on Zeon freeze tolerance. Nitrogen applied from the nitric form yielded a similar effect with a 2 weeks delay. Differences between the two treatments and the untreated control were not detectable at 8 weeks after nitrogen application. Changes in non-structural carbohydrates (starch, glucose, fructose and sucrose) were also induced by the treatments applied but no clear association with freeze tolerance was found (Pompeiano et al., 2013a).

Overseeding with perennial ryegrass is routinely adopted to provide green colour to dormant warm season turfgrasses, however this practice has met limited success with zoysiagrass. Successful establishment of the cool season grass is often followed by a decline in post-dormancy green up with the most likely causes to be attributed to canopy disruption at seeding, allelopathic effects or competition for light and nutrients (Willis and Askew, 2004).

\section{General management}

A typical aspect of zoysiagrasses is the development of a thick thatch layer if not properly managed. While avoiding excessive application of nitrogen fertiliser and the adoption of frequent mowing represent a prevention strategy, vertical mowing and coring may be needed to remove any thatch build up at soil surface (Duble, 2001).

The application of trinexapac-ethyl can help reducing mowing requirements and extending turf colour in the fall. A single summer application of trinexapac-ethyl $\left(0.38 \mathrm{~kg} \mathrm{ha}^{-1}\right.$ of commercial product having $120 \mathrm{~g}$ a.i. $\mathrm{L}^{-1}$ concentration) on Zenith and Companion zoysiagrasses caused a discoloration that lasted for 5 weeks with colour enhancement from 6 to 10 Week After Initial Treatment (WAIT). Overall negative effect on quality was recorded until 7 WAIT. With sequential summer application (treatment repeated at 4 WAIT) discoloration was prolonged until 7 WAIT with colour being enhanced from 8 to 12 WAIT. The effect on quality was a further reduction that lasted until 10 WAIT. Single fall application caused a $35 \%$ average colour decline compared to untreated control of zoysiagrass at 9 WAIT while quality fell below acceptable values within one week. A $44 \%$ average colour decline and a further worsening of quality were observed with sequential fall application. The decrease of colour and visual quality due to fall trinexapac-ethyl treatments was associated to a more rapid progression into dormancy. Zoysiagrass receiving single trinexapacethyl treatments in fall showed a 30 days delay in spring green up. Green up of plots receiving sequential applications was slower compared to that of single application (Severmutlu et al., 2012a). A single summer application reduced vertical growth of zoysiagrass from 1 to 8 WAIT while sequential summer application extended vertical growth suppression of 3 weeks (Severmutlu et al., 2012b).

A further aspect of winter management of dormant turf of zoysiagrass is the applications of glyphosate intended to control winter annual weeds. Research was conducted to investigate potential negative effects on spring green up following glyphosate application on dormant turf. A single application of glyphosate at $1.1 \mathrm{~kg} \mathrm{ha}^{-1}$ in February effectively controlled winter weeds on $Z$. japonica Companion and on Z. matrella Zeon but, while spring green up of Companion was delayed, Zeon did not show the same effect. Authors concluded that winter treatments with glyphosate on dormant zoysiagrass turf cannot be considered a safe practice yet and preliminary evaluations should be performed on a cultivarby-cultivar basis (Rimi et al., 2012a).

When actively growing zoysiagrass is in general able to resist weed invasion more than other turfgrasses due to its dense growth habit (Unruh et al., 2011). Variability in competitiveness of zoysiagrass cultivars has been documented while aeration treatments and nitrogen fertilisation can play a significant role in reducing ground cover and stimulating weed proliferation (Busey, 2003).

Zoysiagrass is also relatively free of serious disease problems (Duble, 2001) with only occasional occurrence of rust (Puccinia spp.) being reported in Italy (Croce et al., 2001). Proper management practices including proper fertilisation and irrigation will 
help reduce damage from rust; zoysiagrass turf damage usually recovers when environmental conditions change (Windham, 1996). To authors' knowledge, as for other warm season turfgrasses, insect problems in Europe are at present absent or negligible.

\section{Turfgrass monitoring through remote sensing}

Monitoring turfgrass status is a fundamental step in management strategies. Proximity sensed spectral reflectance is an established and reliable practice for the purpose of capturing data on several aspects of plant nutrition, deficiencies and/or stress. Different combinations of reflectance values recorded in different bands of the spectrum provide several vegetation indexes that can amplify differences in reflectance spectra and possibly highlight differences in the canopies that have generated them.

With the aim of evaluating spectral reflectance as a diagnostic tool for turfgrasses, Caturegli et al. (2014) acquired proximity sensed spectral reflectance of 20 turfgrass species and cultivars and determined agronomic and biological traits in order to possibly find spectral signatures of species and cultivars for future use on remotely sensed data. Concerning zoysiagrasses only, results revealed that MCARI (Modified Chlorophyll Absorption in Reflectance Index) and TCARI (Transformed Chlorophyll Absorption in Reflectance Index) vegetation indexes could discriminate between japonica types (De Anza, Meyer and Zenith) based on turf quality differences. On the other hand, fine-leaved zoysiagrasses (Z. japonica $\times$ pacifica hybrid Emerald, Z. matrella Zeon and Z. pacifica) did not differ for agronomic and biological traits yet three vegetation indexes, namely $\mathrm{SR}_{900}$ (Simple Ratio Index), VI (Vegetation Index) and WI (Water index), allowed to discriminate between the three species revealing that specific spectral signature can be associated to a given turfgrass species or cultivar.

In order to assess the possibility of gathering turf spectral reflectance via remotely sensed data the acquisition of spectral reflectance via World View 2 satellite imagery was simulated by Caturegli et al. (2015b). In particular, proximity sensed spectral reflectance of the same entries as above was used to calculate vegetation indexes only using the wavelengths available through World View 2 satellite imagery. Due to the availability of specific spectral bands a restricted number of vegetation indexes can be calculated with data provided by World View 2 satellite and such indexes could not discriminate between entries as efficiently as it is possible when the entire set of wavelengths is available.

Among a wide number of vegetation indexes, NDVI is considered a good indicator of many plant growth factors. The possibility to expand the acquisition means from hand held groundbased instruments to GeoEye-1 satellite imagery has been explored. With this aim a comparison has been made between spectral reflectance acquired via two ground based instruments and GeoEye-1 satellite imagery referring to five different turfgrasses on which a gradient of nitrogen content was artificially induced by increasing application rates of fertiliser. Limiting the discussion of research outcomes to the sole zoysiagrasses, manilagrass was less responsive to nitrogen fertilisation with nitrogen content in clippings showing a limited variation compared to the hybrid bermudagrass receiving the same amount of fertiliser. Nonetheless NDVI derived from satellite-sensed data was highly correlated with the data acquired by ground based instruments and with manilagrass clippings nitrogen content. It was concluded that manilagrass nitrogen status and its variability in the field can ade- quately be assessed both via hand held proximity instruments as well as via GeoEye-1 multispectral imagery. The latter option could help to quickly gather information on turfgrass areas as large as golf courses, parks, and sod farms (Caturegli et al., 2015a).

Unmanned aerial vehicles are becoming widespread for a number of applications and turf image acquisition could be easier and cheaper compared to satellite and hand held instruments when medium scale land surfaces are involved. In a comparison of spectral reflectance data acquired both via unmanned aerial vehicle and hand held instrument, good correlation has been found in Zoysia matrella Zeon clippings nitrogen and remotely sensed NDVI, be it acquired via hand held instrument or unmanned aerial vehicle. This recent findings might be the basis for innovative management tools both on small and large-scale zoysiagrass installations (Caturegli et al., 2016).

Remote sensing of nitrogen status in turfgrass has been determined also with a flourescence-based method. While proximal sensing instruments based on spectral reflectance rely on natural light conditions for measurements, florescence-based instruments use an artificial light source and detect the fluorescence of some pigments to specific wavelengths. In a field trial carried out on $Z$. matrella the fluorescence-based instrument was found to be very efficient in discriminating the different $\mathrm{N}$ rate of soil fertilisation. The efficiency in detecting nitrogen status, the possibility to take measurements regardless of light conditions or cloud cover and the insensitiveness to turf density/soil bias make the fluorescencebased methods an important technical improvement in the nondestructive monitoring of turf nitrogen status (Agati et al. 2013).

\section{Sports use}

Wear resistance and recuperative potential are key features for a turfgrass to be selected and established for sports purposes. With the aim of directly determining mechanical characteristics of warm-season turfgrasses Lulli et al. (2011b) measured the tissue tensile strength of leaves, rhizomes and stolons sampled from mature stands of $C$. dactylon $\times$ transvaalensis Tifway, Z. matrella Zeon and P. vaginatum Salam. Results showed that Zeon zoysiagrass was the species with the highest tensile strength per unit area in all organs. Determination of tissue composition revealed zoysiagrass as having the most lignified tissues therefore lignin content was identified as the main factor determining organ tissue strength (Lulli et al., 2011a). Shear strength of stolons was also determined and again $Z$. matrella resulted the most resistant to shear compared with hybrid bermudagrass Tifway and $P$. vaginatum Salam. Shear strength was in general associated with stolon tissue age (Lulli et al., 2011b).

In a subsequent research physiological and morphological traits of three warm season turfgrasses were determined to investigate their potential association with wear resistance and recovery. Compared to $C$. dactylon $\times$ transvaalensis Tifway and $P$. vaginatum Salam, Z. matrella Zeon was the turf that, in a given volume of sod, had the highest linear extent and volume of all rhizomes and stolons and the highest number of nodes. The hypothesis that such architecture might be associated with high wear resistance (imparted by the mechanical action of stems) and high recuperative potential (imparted by an elevated number of growing points fuelled by a large volume of storage tissues) was only partially verified. While the measured superior wear resistance of Zeon was confirmed and attributed in part to the high lignin con- 
tent in its organs, nor the number of point of potential regrowth nor the volume of storage tissues turned into a superior recuperative potential, this providing the evidence that recuperative potential is predominantly determined by tissue constituents and physiological aspects and not by mere biometrics (Lulli et al., 2012).

Apart from wear resistance and recuperative potential, the suitability of a turf surface for a given sport activity is mainly determined by mechanical properties that affect the interaction of the turf with the player and/or the ball. Mechanical properties are in turn determined by plant canopy architecture and soil properties. In a study conducted in 2012 in Pisa the association between some warm season turfgrasses traits and playing characteristics for soccer was investigated on Tifway bermudagrass, Zeon manilagrass and Salam seashore paspalum. In particular, canopy architecture (horizontal stem section, horizontal stem density, shoot density, leaf width, leaf thickness and leaf section area) and leaf constituents (silica, lignin and water content) were measured. Playing quality of the same turfs was also determined through the set of measurements adopted by the Féderation Internationale des Football Associations (FIFA) to test playing characteristics of synthetic soccer pitches, namely ball roll, surface hardness, maximum hardness, maximum hardness depth, traction, vertical ball rebound, angle ball rebound, shock absorption and vertical deformation (FIFA, 2008). Results indicated that Zeon zoysiagrass provides the turf with the highest traction compared to the other turfgrasses in the study this being associated with the presence of a much denser and shallower horizontal stem system. Apart from due considerations on wear resistance and recovery as well as on maintenance standards, the general performance of Zeon zoysiagrass, as assessed in the comparison, was judged as one of best surfaces for soccer given its compliance with the most restrictive parameters of objective evaluation (Lulli et al., 2014).

\section{Green roofs}

Green roofs construction requires the identification of a correct balance between lightweight solutions and the ability of plants to survive and maintain a pleasant appeal. Z. matrella Zeon has a number of desirable traits for green roof applications. Tolerance to moisture deficit and shade, limited vertical growth that require minimal mowing, development of a dense mat of vertical and horizontal organs that limit weed invasion and short brown period due to early spring green up and color retention till late fall. In a trial carried out in Greece Z. matrella Zeon was grown in green roof conditions i.e. with shallow substrates under moisture deficit. The experimental design included two substrate types with different water retention curves, two-substrate depth (7.5 and $15 \mathrm{~cm}$ ) and two irrigation regimes (20 and 40\% of actual evapotranspiration). In the trial environmental conditions the turfgrass was not able to maintain green cover for the entire period of moisture deficit (4 weeks in 2010 and 5 weeks in 2011) with growth arrest occurring after 18 days of limited irrigation (Ntoulas et al., 2013b). Green cover was mostly affected by substrate depth that probably allowed zoysiagrass to express its drought mechanism which involves a reduction of surface roots and a root system redistribution into deeper soil layers (Ntoulas et al., 2013a).

\section{Current use and culture of zoysiagrass in Europe}

In about two decades research in Europe has provided extensive knowledge on aspects of zoysiagrass ranging from descriptive traits of the different cultivars, their adaptation to different environments, the fall and winter performance also including its tolerance to some specific stresses and adaptability to specific uses. European turf managers today have access to a huge amount of scientific and professional information both from international literature and from European based research while zoysiagrass plant material is more accessible both from seed and vegetative source than in the past. Despite the concurrence of several positive conditions the decision to use a specific turfgrass species still lays on personal preferences and general perception among experienced practitioners is that zoysiagrass is underused in Europe and not fully exploited for its potential benefits. Both for sod production and seed trade, zoysiagass plays a marginal role. While bermudagrass use for sports surfaces is sustained by technical reasons mainly related to the aggressive lateral growth and the high recuperative potential, zoysiagrass use would be mostly appropriate for home gardens and parks where aesthetic value and low management requirements represent desirable traits. For this application winter dormancy represents a major drawback.

Zoysiagrass sod production in Europe is very limited. According to the European Turgrass Producers (2016) only foursod farm produce zoysiagrass of which three are located in Italy and one in Spain. To authors' knowledge, one sod farm in Slovakia started testing zoysiagrass in the mid ' 80 and started the production of 10 ha of $Z$. japonica Zenith in 2004. Market demand however is low. In Greece sod farms don't produce any zoysiagrass and consider it not profitable due to slow growth and low customer demand. The only small areas that can be found have been established by seed. In Turkey zoysiagrass is produced by two smallscale farms and the market request seems to increase.

Besides the published research reported above, field trials and demonstration plots of zoysiagrass had been installed in Brno (Czeck Republic) at Mendel University, and at the University of Bari (Italy) (Marchione, 2012)

Still not representing a major market demand, zoysiagrass use is increasing in popularity in the European golf industry. Slow growth, high density of horizontal and vertical stems make Zoysia the ideal turf for golf green collars where it acts as buffer between the putting surface, be it bentgrass or dwarf bermudagrass, and the bermudagrass surround. The slow growth of zoysiagrass is appreciated also for bunker slopes where it can be an effective system to limit the frequent trimmings and brushing that are needed to maintain steep slopes and sharp edges. Further, the reduction of chemical inputs that will be allowed on turf by European laws and regulations will make zoysiagrasses more attractive for their suitability to low input management.

\section{Conclusions}

These new trends in golf are well represented by some golf clubs in the surroundings of Hamburg, northern Germany, that are using zoysiagrass for bunker faces or pot bunkers. Using zoysiagrass at $53^{\circ} 33^{\prime} \mathrm{N}$ latitude is well beyond any trial result for the adaptation to the European environment. 


\section{References}

Agati G, Foschi L, Grossi N, Guglielminetti L, Cerovic ZC, Volterrani M, 2013. Fluorescence-based versus reflectance proximal sensing of nitrogen content in Paspalum vaginatum and Zoysia matrella turfgrasses. Eur. J. Agron. 45:39-51.

Busey P, 2003. Cultural management of weeds in turfgrass: a Review. Crop Sci. 43:1899-911.

Caturegli L, Casucci M, Lulli F, Grossi N, Gaetani M, Magni S, Bonari E, Volterrani M, 2015a. GeoEye-1 satellite versus ground-based multispectral data for estimating nitrogen status of turfgrasses. Int. J. Remot. Sens. 36:2238-51.

Caturegli L, Corniglia M, Gaetani M, Grossi N, Magni S, Migliazzi M, Angelini L, Mazzoncini M, Silvestri N, Fontanelli M, Raffaelli M, Peruzzi A, Volterrani M, 2016. Unmanned aerial vehicle to estimate nitrogen status of turfgrasses. PLos One 11:e0158268.

Caturegli L, Lulli F, Foschi L, Guglielminetti L, Bonari E, Volterrani M, 2014. Monitoring turfgrass species and cultivars by spectral reflectance. Eur. J. Hortic. Sci. 79:97-107.

Caturegli L, Lulli F, Foschi L, Guglielminetti L, Bonari E, Volterrani M, 2015b. Turfgrass spectral reflectance: simulating satellite monitoring of spectral signatures of main $\mathrm{C}_{3}$ and $\mathrm{C}_{4}$ species. Precis. Agric. 16:297-310.

Croce P, De Luca A, Mocioni M, Volterrani M, Beard JB, 1999. Seeded and vegetatively propagated cultivar comparisons within both Cynodon and Zoysia species. Proc. $4^{\text {th }}$ International Herbage Seed Conference, Perugia, 23-27 May, pp. $47-51$.

Croce P, De Luca A, Mocioni M, Volterrani M, Beard JB, 2001. Warm-season turfgrass species and cultivar characterizations for Mediterranean climate. Int. Turfgrass Soc. Res. J. 9:855-9.

Croce P, De Luca A, Mocioni M, Volterrani M, Beard JB, 2004. Adaptability of warmseason turfgrass species and cultivars in a Mediterranean climate. Acta Hort. 661:365-8.

De Luca A, Volterrani M, Gaetani M, Grossi N, Croce P, Mocioni M, Lulli F. 2008. Warm season turfgrass adaptation in Europe north of the $45^{\circ}$ parallel. Proc. V World Scientific Congress of Golf, March 24-28, 2008. Phoenix, AZ, USA.

Duble RL, 2001. Turfgrasses: their management and use in the southern zone (Vol. 20). Texas A\&M University Press, College Station, TX, USA.

Engelke MC, Anderson SJ, 2003. Zoysiagrasses. In: M.D. Casler and R.R. Duncan (eds.) Turfgrass biology, genetics, and breeding. John Wiley \& Sons, Hoboken, NJ, USA, pp. 271-285.

European Turgrass Producers, 2016. Available from: www.turfgrassproducers.eu

FIFA, 2008. FIFA quality concept for artificial turf. Handbook of test methods. Fédération Internationale de Football Association, Zurich, Switzerland.

Foy J, 2006. Selecting the right grass. Available from: http:/gsrpdf.lib.msu.edu/ticpdf.py?file=/2000s/2006/061101.pdf

Gaetani M, Lulli F, Andreucci A, Masini A, Vittori G, Volterrani M, 2013. Sprouting and plant regeneration capability in saline condition of seashore paspalum, Manilagrass, and hybrid bermudagrass stolons. Propag. Ornament. Plants 13:57-64.

Geren H, Avcioglu R, Curaoglu M, 2009. Performances of some warm-season turfgrasses under Mediterranean conditions. Afr. J. Biotechnol. 8:4469-74.

Layt TA, 2011. Zoysia macrantha plant named 'MAC03'. United States Plant Patent No. US PP21,789 P3.

Lulli F, de Bertoldi C, Armeni R, Guglielminetti L, Volterrani M,
2014. Warm season turfgrass species generate sports surfaces with different playability. HortTechnology 24:749-56.

Lulli F, Guglielminetti L, Grossi N, Armeni R, Stefanini S, Volterrani M, 2011a. Physiological and morphological factors influencing leaf, rhizome and stolon tensile strength in $\mathrm{C} 4$ turfgrass species. Funct. Plant Biol. 38:919-26.

Lulli F, Volterrani M, Grossi N, Armeni R, Stefanini S, Guglielminetti L, 2012. Physiological and morphological factors influencing wear resistance and recovery in $\mathrm{C} 3$ and $\mathrm{C} 4$ turfgrass species. Funct. Plant Biol. 39:214-21.

Lulli F, Volterrani M, Grossi N, Gaetani M, Magni S, Caturegli L, Armeni R, 2011b. Resistenza meccanica allo sforzo di taglio negli stoloni delle specie C4 da tappeto erboso. XL Convegno della Società Italiana di Agronomia, Teramo 7-9 Sept. 2011, pp. 220-221.

Macolino S, Ziliotto U, Leinauer B, 2012. Comparison of turf performance and root systems of bermudagrass cultivars and 'Companion' zoysiagrass. Acta Hort. 938:185-90.

Marchione V, 2012. Effect of different irrigation regimes on turf quality of warm season species in Mediterranean climate. Bioforsk Fokus, Landvik, Norway, pp. 48-50.

Miele S, Volterrani M, Grossi N, 2000. Warm season turfgrasses: result of a five-year study in Tuscany. Agric. Medit. 130:1-9.

Ntoulas N, Nektarios PA, Charalambous E, Psaroulis A, 2013a. Zoysia matrella cover rate and drought tolerance in adaptive extensive green roof systems. Urb. Forest. Urban Green. 12:522-31.

Ntoulas N, Nektarios PA, Nydrioti E, 2013b. Performance of Zoysia matrella 'Zeon' in shallow green roof substrates under moisture deficit conditions. HortScience 48:929-37.

Panella A, 1972. Tappeti erbosi. Impianto, manutenzione e impieghi. Edagricole, Bologna, Italy.

Pompeiano A, Caturegli L, Grossi N, Volterrani M, Guglielminetti L, 2015. Carbohydrate Metabolism during wintering period in zoysiagrass genotypes. Plant Prod. Sci. 18:43-51.

Pompeiano A, Giannini V, Gaetani M, Vita F, Guglielminetti L, Bonari E, Volterrani M, 2014a. Response of warm-season grasses to $\mathrm{N}$ fertilization and salinity. Scientia Horticulturae 177:92-8

Pompeiano A, Grossi N, Guglielminetti L, Volterrani M, 2014b. Winter color retention and spring green-up of zoysiagrass genotypes in southern Europe. Europ J. Hort. Sci 79:158-66.

Pompeiano A, Grossi N, Volterrani M, 2012. Vegetative establishment rate and stolon growth characteristics of 10 zoysiagrasses in southern Europe. HortTechnology 22:1-7.

Pompeiano A, Guglielminetti L, Volterrani M, 2011. Freeze tolerance of Zoysia matrella (L.) Merrill as affected by late-season nitrogen application, and changes in carbohydrates during cold acclimation. Plant Biosyst. 145:885-92.

Pompeiano A, Volpi I, Volterrani M, Guglielminetti L, 2013a. N source affects freeze tolerance in bermudagrass and zoysiagrass. Acta Agric. Scandin. B 63:341-51.

Pompeiano A, Volterrani M, Guglielminetti L, 2013b. Physiological responses of $\mathrm{C}_{4}$ grasses to prolonged heat stress. Adv. Hort. Sci. 27:127-32.

Qian YL, Engelke MC, Foster MJV, 2014. Salinity effects on zoysiagrass cultivars and experimental lines. Crop Sci. 40:488-92.

Rimi F, Macolino S, Leinauer B, 2012a. Winter-applied glyphosate effects on spring green-up of zoysiagrasses and 'Yukon' bermudagrass in a transition zone. HortTechnology 22:131-6.

Rimi F, Macolino S, Ziliotto U, 2012b. Rooting characteristics and turfgrass quality of three bermudagrass cultivars and a zoysiagrass. Acta Agriculturae Scandinavica Section B - Soil and 
Plant Science 62:24-31.

Severmutlu S, Mutlu N, Gurbuz E, Gulsen O, Hocagil M, Kataguzel O, Heng-Moss T, Shearman RC, Gaussoin RE, 2011b. Drought resistance of warm-season turfgrasses grown in mediterranean region of Turkey. HortTechnology 21:726-36.

Severmutlu S, Mutlu N, Gurbuz E, Shearman RC, Riordan TP, 2012a. Effects of seasonal trinexapac-ethyl application on warm season turfgrass colour, quality and spring green-up under mediterranean environment. J. Horticult. Sci. 77:226-36.

Severmutlu S, Mutlu N, Gurbuz E, Shearman RC, Riordan TP, 2012b. Effects of seasonal trinexapac-ethyl application on warm season turfgrass species growth under Mediterranean environment. Europ. J. Hort. Sci. 77:279-87.

Severmutlu S, Mutlu N, Shearman RC, Gurbuz E, Gulsen O, Hocagil M, Kataguzel O, Heng-Moss T, Riordan TP, Gaussoin RE, 2011a. Establishment and turf qualities of warm-season turfgrasses in the Mediterranean region. HortTechnology 21:67-81.

Unruh JB, Trenholm LE, Cisar JL, 2011. Zoysiagrass for Florida Lawns. University of Florida, IFAS Extension, Gainesville, FL, USA.

van Wijk AJP, 1993. Turfgrasses in Europe: cultivar evaluation and advances in breeding. Int. Turf. Soc. Res. 7:26-38.

Volterrani M, Grossi N, Gaetani M, Pompeiano A, 2010a. Zoysiagrass cultivar establishment rate and turf quality in cen- tral Italy. Acta Hort. 881:313-6.

Volterrani M, Grossi N, Lulli F, Gaetani M, 2008. Establishment of warm-season turfgrass species by transplant of single potted plants. Acta Hort. 783:77-84.

Volterrani M, Grossi N, Magni S, Lulli F, Pompeiano A, $2010 \mathrm{~b}$. Zoysia matrella response to late-fall fertilization in the transition zone. Proc. of the $2^{\text {nd }}$ European Turfgrass Society Conference. Angers (France), 12-14 ${ }^{\text {th }}$ April 2010, p. 225-227.

Volterrani M, Grossi N, Pardini G, Miele S, Gaetani M, Magni S, 1997. Warm season turfgrass adaptation in Italy. Int. Turf. Soc. Res. 8:1344-54.

Volterrani M, Pardini G, Grossi N, Miele S, Gaetani M, Pietrini E, 1996. Valutazione dell'adattabilità di specie graminacee macroterme da tappeti erbosi alle condizioni ambientali dell'Italia centrale. Italus Hortus 3:10-6.

Willis JB, Askew SD, 2004. Effect of fall preparation and spring transition method on overseeded zoysiagrass vigor and quality. Annual Meeting Abstract ASA/CSSA/SSSA/CSSS, Seattle WA, USA. Available from: https://download.clib.psu.ac.th/ datawebclib/e_resource/e_database/agronomy/2004/Browse/p df/ACS/6323.pdf

Windham A, 1996. Turfgrass diseases and their control. University of Tennessee Agricultural Extension Service, Knoxville, TN, USA. 